\title{
The life cycle assessment of automotive biological butanol
}

\author{
Hu Zhiyuan ${ }^{1}$ \& Ding Yushan ${ }^{1}$ \& Song Hao ${ }^{1}$
}

${ }^{1}$ School of Automotive Studies, Tongji University, Shanghai, 201804

\begin{abstract}
KEYWORD: Biological Butanol; Life Cycle Assessment; Energy Consumption; Emission; Economy

ABSTRACT: A life cycle energy, emission and economic assessment model of biological butanolgasoline blend fuel was established based on life cycle. Then, the life cycle energy, environment, and economy of biological butanol-gasoline blend fuel used as automotive fuel were assessed. Comparing with conventional gasoline, biological butanol-gasoline blend fuel has higher life-cycle total energy, and fossil fuels consumption, higher $\mathrm{HC}, \mathrm{NO}_{\mathrm{X}}, \mathrm{SO}_{\mathrm{X}}, \mathrm{PM}$, and $\mathrm{CO}_{2}$ pollutants, higher life cycle cost, lower petroleum consumption, lower $\mathrm{CO}$, and $\mathrm{CH}_{4}$ pollutants. The promotion and application of biological butanol is beneficial for vehicles to reduce the consumption of oil, but needs subsidy.
\end{abstract}

\section{INTRODUCTION}

The main fuel used in cars are gasoline and diesel refined from oil. In recent years, China's civil car ownership has been growing rapidly. The oil consumption of vehicles is growing rapidly, thus, taking measures to reduce the oil consumption of vehicles, is one of the hot issues that we face. Butanol has the characteristics of wide source of raw materials, high calorific value, high boiling point, high octane value, low vapor pressure, low corrosiveness, with gasoline in any proportion and good transportation safety ${ }^{[1][2]}$, is one of the good gasoline alternative fuels, which get attention in many countries ${ }^{[3]}$.

Life cycle assessment is a process to evaluate the environmental burdens associated with a product, process, or activity by identifying and quantifying energy and materials used and wastes released to the environment ${ }^{[4]}$. As an important decision-making tool, life cycle assessment is used widely in "well-to-wheels" life cycle inventory analysis of ethanol ${ }^{[5]}$, methanol ${ }^{[6]}$, biodiesel ${ }^{[7]}$, DME ${ }^{[8]}$ and other gasoline alternative fuels, which provide a useful date support to promote the use of gasoline alternative fuels. Currently, the research on biological butanol is focused on the influence of butanol on engine materials ${ }^{[9]}$, the combustion and emission characteristics of engines ${ }^{[10]}$, the actual road test of vehicles ${ }^{[11]}$, and the research on biological butanol is still absent.

Based on the life cycle assessment theory, this paper make a life cycle inventory analysis of biological butanol, then analysis the input and output proportion of the plantation and transportation of raw materials, the production and transportation of biological butanol, the usage of biological butanol in vehicles in entire life cycle, make a systematic review for the impact on environment and energy consumption in biological butanol life cycle.

\section{BIOLOGICAL BUTANOL LIFE CYCLE ANALYSIS}

\section{Objectives and scope of the study}

The automotive biological butanol life cycle is the system process from "raw material planting" to "combustion/vehicle use", is composed of "raw material production", "biological butanol production" and "biological butanol combustion/vehicle use" this three sub-processes. The automotive biological butanol life cycle is mainly consist of the processes of "chemicals production and transportation", "raw material production", "raw material processing and transportation", "biological butanol production", "biological butanol transportation", "fuel mixed", and "biological butanol combustion/vehicle use", as is shown in figure 1. 


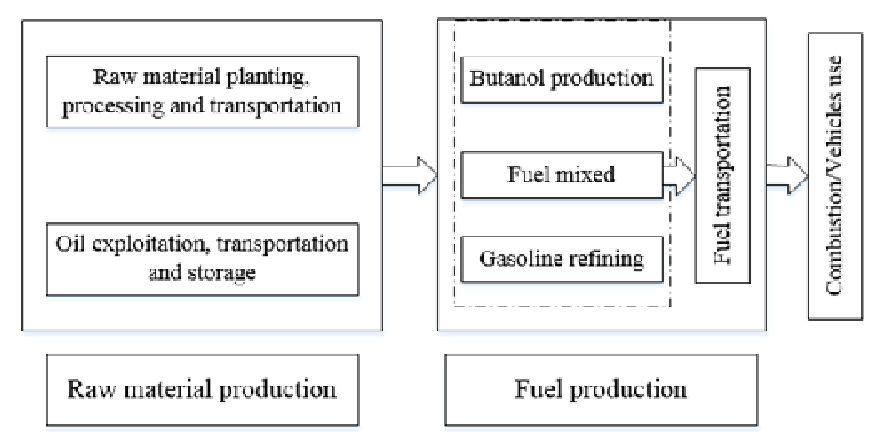

Figure 1. Life cycle framework of biological butanol.

Currently, cassava is main raw material that produce biological butanol in China, the source mainly rely on imports from Laos, Vietnam, Thailand and other Southeast Asian countries. Tapioca slice first transported to wharfs in China from the wharfs in Southeast Asia, and then transported to the manufacturers from the wharfs in China by train. The production of biological butanol is mainly by way of fermentation, first, pulverizing the Tapioca slice to power, adding water to power in order to transform power to mash, then adding clostridium acetobutylicum in the mash, letting the mash ferment in the temperature of $36 \sim 37^{\circ} \mathrm{C}$ to obtain n-butanol and acetone, distilling the mixture of nbutanol and acetone to get n-butanol. Butanol transported to destinations by train or truck, then mixed with gasoline in a certain proportion, and transported to gas stations for vehicles.

\section{Evaluation indicators}

The life cycle assessment of biological butanol is composed of energy consumption, environmental emissions and economic analysis, and energy consumption index is mainly composed of the consumption of coal, oil and other fossil fuels, petroleum consumption in the life cycle of biological butanol and each stage. Environmental emissions is mainly composed of $\mathrm{CO}, \mathrm{PM}, \mathrm{NO}_{\mathrm{X}}$, and $\mathrm{CO}_{2}$ pollutant emission in the life cycle of biological butanol and each stage, as is shown in figure 2 .

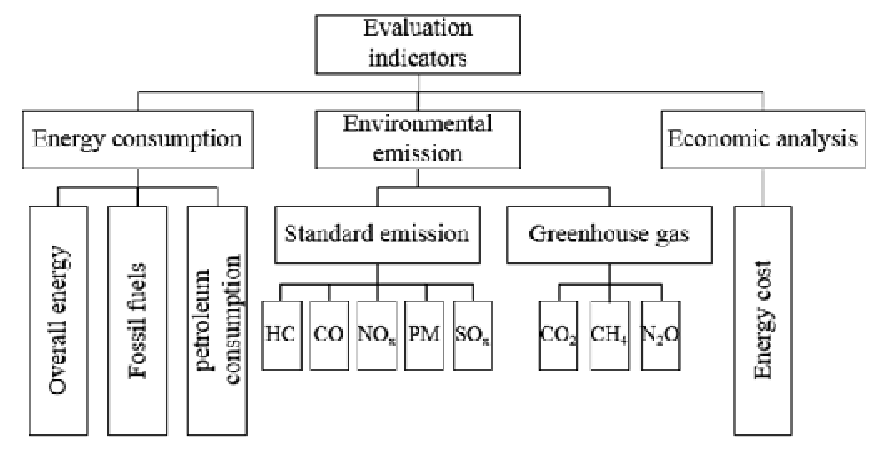

\section{Functional unit}

Figure 2. The indicators of life cycle assessment.

Currently, the research on the proportion of biological butanol-gasoline blend fuel is focused on the proportions: $10 \%, 20 \%{ }^{[12,13]}, 48 \%, 85 \%$ and $100 \%{ }^{[14]}$. Taking a gasoline car with fuel consumption of $7 \mathrm{~L} / 100 \mathrm{~km}$ (mixed working condition), or biological butanol-gasoline blend fuel cars with equal performance compared with gasoline car as the research object, fuel consumption per hundred kilometers of biological butanol-gasoline blend fuel cars is obtained on the basis of the calorific value of gasoline and butanol, therefore, the fuel consumption per hundred kilometers of biological butanol-gasoline blend fuel cars are: $7.09 \mathrm{~L} / 100 \mathrm{~km} 、 7.19 \mathrm{~L} \mathrm{~L} / 100 \mathrm{~km} 、 7.48 \mathrm{~L} \mathrm{~L} / 100 \mathrm{~km} 、 7.89 \mathrm{~L}$ $\mathrm{L} / 100 \mathrm{~km}$ and $8.07 \mathrm{~L} \mathrm{~L} / 100 \mathrm{~km}$ in different mixed proportions. 


\section{Date sources}

Getting the reliable date is the basis of life cycle assessment, the dates of energy consumption, pollutant discharge coefficient, pollutant emission of the life cycle of biological butanol-gasoline blend fuel vehicles and conventional gasoline vehicles are from domestic and foreign public documents literatures. The dates of partial pollutant discharge coefficient, pollutant emissions in the usage stage of alternative fuels are from the US Argonne National Laboratory's GREET model. The energy consumption dates in the biological butanol production are getting from field research.

\section{EVALUATE RESULTS}

\section{The life cycle energy consumption}

The life cycle energy consumption of gasoline, $\mathrm{Bu} 10, \mathrm{Bu} 20, \mathrm{Bu} 48, \mathrm{Bu} 85, \mathrm{Bu} 100$ and other different mixing proportions of biological butanol and gasoline blend fuels as shown in table1. Comparing with gasoline, the life cycle energy consumption of biological butanol-gasoline blend fuel is higher, and the life cycle energy consumption of biological butanol-gasoline blend fuel is increase with the increase of biological butanol proportion in the biological butanol-gasoline blend fuel. This is because biological butanol is obtained through fermentation, the fermentation products include $\mathrm{n}$ butanol, acetone, and ethanol. The acquisition of n-butanol needs several times of distillation, the energy consumption is large in the stage of biological butanol production, therefore, the life cycle energy consumption of biological butanol is higher compared with gasoline. At the same time, the vapor used in the biological butanol distillation is from coal, hence the fossil fuels energy consumption is higher compared with gasoline.

Table 1. The life cycle energy consumption of biological butanol-gasoline blend fuel.

\begin{tabular}{|c|c|c|c|c|}
\hline \multirow[t]{2}{*}{ Fuel } & \multicolumn{4}{|c|}{$\begin{array}{l}\text { The life cycle energy consumption } \\
(\mathrm{MJ} / \mathrm{km})\end{array}$} \\
\hline & $\begin{array}{l}\text { Raw } \\
\text { material } \\
\text { produc- } \\
\text { tion }\end{array}$ & $\begin{array}{l}\text { Fuel } \\
\text { produc- } \\
\text { tion }\end{array}$ & $\begin{array}{l}\text { Combus } \\
\text { bus- } \\
\text { tion/veh } \\
\text { icle use }\end{array}$ & $\begin{array}{l}\text { The life } \\
\text { cycle }\end{array}$ \\
\hline $\begin{array}{l}\text { Gaso- } \\
\text { line }\end{array}$ & 0.095 & 0.437 & 2.248 & 2.780 \\
\hline Bu10 & 0.139 & 0.795 & 2.177 & 3.115 \\
\hline $\mathrm{Bu} 20$ & 0.183 & 1.162 & 2.177 & 3.531 \\
\hline $\mathrm{Bu} 48$ & 0.314 & 2.247 & 2.177 & 4.759 \\
\hline Bu85 & 0.504 & 3.820 & 2.177 & 6.539 \\
\hline $\mathrm{Bu} 100$ & 0.588 & 4.507 & 2.177 & 7.317 \\
\hline
\end{tabular}

Biological butanol is a kind of renewable energy, the promotion and application of biological butanol is beneficial for vehicles to reduce the consumption of oil. The life cycle petroleum consumption of gasoline, $\mathrm{Bu} 10, \mathrm{Bu} 20, \mathrm{Bu} 84$ and $\mathrm{Bu} 100$ and other different mixing proportions of biological butanol and gasoline blend fuels as shown in table 2. Comparing with conventional gasoline, biological butanol-gasoline blend fuel in all proportions has lower life cycle petroleum consumption, the magnitude of the decrease of biological butanol-gasoline blend fuel life cycle petroleum consumption is increase with the increase of biological butanol proportion in the biological butanolgasoline blend fuel. 
Table 2. The life cycle petroleum consumption of biological butanol-gasoline blend fuel.

\begin{tabular}{lllll}
\hline \multirow{2}{*}{ Fuel } & $\begin{array}{l}\text { The life } \\
(\mathrm{MJ} / \mathrm{km})\end{array}$ & cycle energy consumption \\
\cline { 2 - 5 } & $\begin{array}{l}\text { Raw } \\
\text { material } \\
\text { produc- } \\
\text { tion }\end{array}$ & $\begin{array}{l}\text { Fuel } \\
\text { produc- } \\
\text { tion }\end{array}$ & $\begin{array}{l}\text { Com- } \\
\text { bus- } \\
\text { tion/veh } \\
\text { icle use }\end{array}$ & $\begin{array}{l}\text { The life } \\
\text { cycle }\end{array}$ \\
\hline $\begin{array}{l}\text { Gaso- } \\
\text { line }\end{array}$ & 0.028 & 0.219 & 2.177 & 2.425 \\
Bu10 & 0.029 & 0.204 & 1.986 & 2.223 \\
Bu20 & 0.031 & 0.188 & 1.789 & 2.015 \\
Bu48 & 0.034 & 0.142 & 1.209 & 1.403 \\
Bu85 & 0.039 & 0.075 & 0.368 & 0.516 \\
Bu100 & 0.041 & 0.045 & 0 & 0.128 \\
\hline
\end{tabular}

\section{The life cycle emissions}

The life cycle $\mathrm{CO}, \mathrm{HC}, \mathrm{NO}_{\mathrm{X}}, \mathrm{SO}_{\mathrm{X}}, \mathrm{PM}, \mathrm{CO}_{2}, \mathrm{CH}_{4}, \mathrm{~N}_{2} \mathrm{O}$ emissions of gasoline, $\mathrm{Bu} 10, \mathrm{Bu} 20, \mathrm{Bu} 48$, $\mathrm{Bu} 85, \mathrm{Bu} 100$ and other different mixing proportions of biological butanol and gasoline blend fuels as shown in figure 3. Comparing with conventional gasoline, biological butanol-gasoline blend fuel has lower life cycle $\mathrm{CO}$ and $\mathrm{CH}_{4}$ emissions, higher life cycle $\mathrm{HC}, \mathrm{NO}_{\mathrm{X}}, \mathrm{SO}_{\mathrm{X}}, \mathrm{PM}$ and $\mathrm{CO}_{2}$ emissions, and the $\mathrm{N}_{2} \mathrm{O}$ emission has a litter change. This is because butanol is oxygenated fuel, the CO, $\mathrm{HC}$ emissions in the stage of "biological butanol combustion/vehicle use" is lower compared with gasoline; at the same time, biological butanol is a kind of renewable energy, the $\mathrm{CO}_{2}$ emission in the stage of "biological butanol combustion/vehicle use" is lower compared with gasoline. Besides, because of the larger latent heat of vaporization, the lower intake air temperature leads to the decrease of cylinder combustion temperature, hence the $\mathrm{NO}_{\mathrm{X}}$ emission is decrease. However, the energy consumption and the pollutant emission in the stage of "biological butanol production" are higher compared with gasoline, the above factors lead to biological butanol-gasoline blend fuel has lower $\mathrm{CO}$, and $\mathrm{CH}_{4}$ emission, higher $\mathrm{HC}, \mathrm{NO}_{\mathrm{X}}, \mathrm{SO}_{\mathrm{X}}, \mathrm{PM}$, and $\mathrm{CO}_{2}$ emissions compared with gasoline. Taking measures to decrease the energy consumption in the stage of "biological butanol production" or using clean energy in this stage to decrease emissions is useful measure to decrease the biological butanol-gasoline blend fuel life cycle emissions.

\section{Economy}

Economy mainly refers to the life cycle cost of butanol, it refers to the entire life cycle of the product, the sum of the cost from the acquisition of raw materials to the abandon or recycle of waste. According to the 2014 socio-economic date to calculate, the cost of biological butanol life cycle is 6.29 yuan/L, and the cost of gasoline life cycle is 5.71 yuan/L. The life cycle cost of gasoline, Bu10, $\mathrm{Bu} 20, \mathrm{Bu} 48, \mathrm{Bu} 85, \mathrm{Bu} 100$ and other different mixing proportions of biological butanol and gasoline blend fuels as shown in table 3. The life cycle cost of biological butanol-gasoline blend fuel is higher compared with gasoline because of the higher life cycle cost of biological butanol. Similar to ethanol fuel, biological butanol-gasoline blend fuel needs subsidy to promote its promotion and application. 


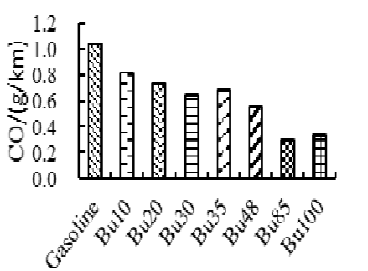

$\mathrm{CO}$ emissions

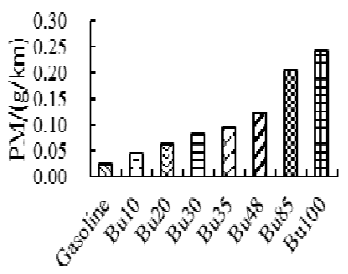

PM emissions

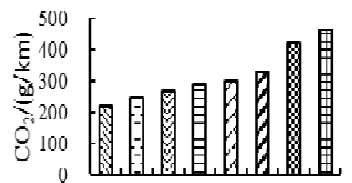

की

$\mathrm{CO}_{2}$ emissions

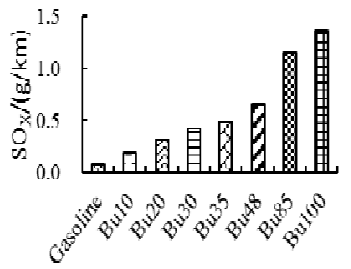

$\mathrm{SO}_{\mathrm{X}}$ emissions

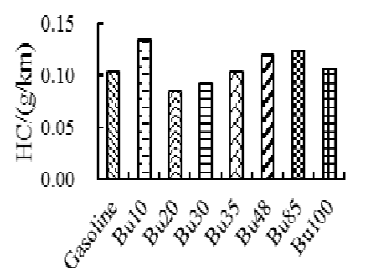

$\mathrm{HC}$ emissions

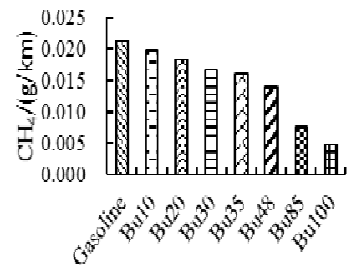

$\mathrm{CH}_{4}$ emissions

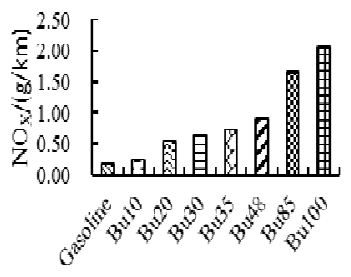

$\mathrm{NO}_{\mathrm{X}}$ emissions

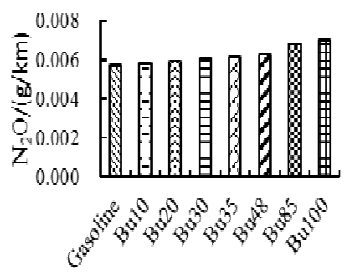

$\mathrm{N}_{2} \mathrm{O}$ emissions

Figure 3. Life Cycle emission of biological butanol-gasoline blend fuel.

Table 3. Life cycle cost of biological butanol-gasoline blend fuel.

\begin{tabular}{|c|c|c|c|c|c|c|}
\hline Fuel & $\begin{array}{l}\text { Gaso- } \\
\text { line }\end{array}$ & Bu10 & $\mathrm{Bu} 20$ & $\mathrm{Bu} 48$ & $\mathrm{Bu} 85$ & $\begin{array}{l}\text { Bu10 } \\
0\end{array}$ \\
\hline $\begin{array}{l}\text { Cost } \quad \text { (yu- } \\
\text { an/L) }\end{array}$ & 4.29 & 4.49 & 4.69 & 5.25 & 5.99 & 6.29 \\
\hline $\begin{array}{l}\text { Cost per } \\
100 \mathrm{~km} \\
(\mathrm{yu}- \\
\text { an } / 100 \mathrm{~km})\end{array}$ & 34.28 & 36.37 & 38.51 & 44.84 & 54.01 & 58.02 \\
\hline
\end{tabular}

\section{CONCLUSIONS}

(1)Comparing with conventional gasoline, the automotive biological butanol-gasoline blend fuel has higher life cycle energy consumption and fossil fuels consumption, lower petroleum consumption. The promotion and application of biological butanol is beneficial for vehicles to reduce the consumption of oil.

(2)Comparing with conventional gasoline, biological butanol-gasoline blend fuel has lower life cycle $\mathrm{CO}$ and $\mathrm{CH}_{4}$ emissions, higher life cycle $\mathrm{HC}, \mathrm{NO}_{\mathrm{X}}, \mathrm{SO}_{\mathrm{X}}, \mathrm{PM}$ and $\mathrm{CO}_{2}$ emissions, and the $\mathrm{N}_{2} \mathrm{O}$ emission has a litter change.

(3)Comparing with conventional gasoline, the life cycle cost of biological butanol-gasoline blend fuel is higher, biological butanol-gasoline blend fuel needs subsidy to promote its promotion and application.

\section{ACKNOWLEDGEMENTS}

This work was supported by the state key laboratory of motor bio-fuel technology open subject "2013010". 


\section{REFERENCES}

[1] Zeng Xianjun, Deng Jian,Kong Hua et al. Research Progress of Butanol as an Alternative Vehicle Fuel [J]. SMALL INTERNAL COMBUSTION ENGINE AND MOTORCYCLE,2012,41 (1): 76-80.

[2] Szwaja S., Naber J. D. Combustion of n-butanol in a spark-ignition IC engine [J]. Fuel, 2010, 89(7): 1573-1582.

[3]Huang Gesheng, Li Zhenyu, et al. The performance advantages and technical progress of biological butanol [J]. Petrochemical Technology \& Application. 2012, 30(3):254-259.

[4] Consoli, F., Allen, D. Boustead, I., Fava, J., et al. Guidelines for life-cycle assessment: a code of practice [M]. Brussels: SETAC Europe, 1993.18-67

[5] M. Wang, C. Saricks, and D. Santini, Effects of Fuel Ethanol Use on Fuel-Cycle Energy and Greenhouse Gas Emissions, http://www.transportation.anl.gov/pdfs/TA/58.pdf

[6]Liu Hong, Wang Hewu, Hou Zhichao, et al. The life cycle assessment of coal-based fuel of methanol vehicles and electric vehicles $[\mathrm{J}]$. Transport energy conservation and environmental protection, 2007(5):27-32

[7] John Sheehan, Vince Camobreco, James Duffield, Michael Graboski, and Housein Shapouri, Life Cycle Inventory of Biodiesel and Petroleum Diesel for Use in an Urban Bus, http://www.nrel.gov/docs/legosti/fy98/24089.pdf

[8] Wang Yin,Life cycle assessment of the natural gas-based and coal-based DME as vehicle fuel,Automotive Safety and Energy,2010,1(3):242-246

[9] Eric W. Thomas. Fluoroelastomer compatibility with bioalcohol fuels [J]. SAE paper, 2009-010994.

[10] Hu Zhiyuan, Yang Qi,Tan Piqian et al. Unregulated Emission Characteristics of EFI Gasoline Engine Fueled with Butanol-Gasoline Blends, Chinese Internal Combustion Engine Engineering, 2014, 35(3):26-30

[11] Lou Diming, Fang Liang, Hu Zhiyuan, Tan Piqiang, Charateristics of On-road Gas Emission from a Diesel PCV with Butanol-diesel Bleds,JOURNAL OF TONGJI UNIVERSITY(NATURAL SCIENCE),2013,46(9):1423-1428

[12] Li Ke, Wang Baolin, et al. An Expermental Study on the Feasibility of Using Butanol-Gasoline Blend Fuels in Gasoline Engine [J]. Automotive Engineering. 2009, 31(09):820-823

[13]Yang Xiaolong, Yang Jing, et al. Experimental Study of the Effects of Butanol-gasoline Blend on Engine Performance [J]. Journal of Hunan University(Natural Sciences).2010, 37(02):32-35

[14]Liu Maobin, He Bangquan, et al. Combustion Characteristics of a HCCI Engine Fuelled with nButanol-Gasoline Blends [J]. Transactions of CSICE. 2013, 31(04):324-330.

[15]The national bureau of statistics of China. China Energy Statistical Yearbook. 2013. Beijing:China Statistics Press, 2014.

[16] http://data.stats.gov.cn/workspace/index?m=hgnd. 